\title{
Towards a non-colonial [divine] service
}

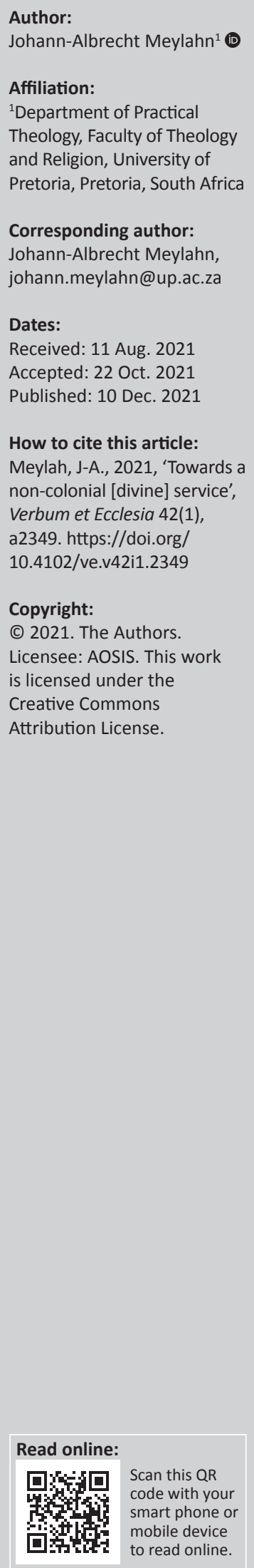

In this article, Schleiermacher's idea of a divine service as mitteilende Darstellung (communicative presentation) will be brought into conversation with Gräb's homiletics as religious speech and then, adding to the conversation, Latour's tormented religious speech. Latour's religious speech will, in turn, be brought into conversation with Rancière's idea of politics in contrast to police, thereby proposing a non-colonial [divine] service, which might have certain similarities with Badiou's interpretation of theatre. However, being vigilant of the constant threat of again becoming colonial. This temptation or danger could be prevented by a communicative presentation (theatrical performance or enactment) of the Christ Event through a Christ-poiēsis that does not colonise time or space but brings into close proximity (communicative presentation) space and time as the fulfilment of time.

Intradisciplinary and/or interdisciplinary implications: The article, 'Towards a non-colonial [divine] service' is written from the South African context, but its relevance is global as it proposes a non-colonial perspective on homiletics and liturgy. It brings together various disciplines (philosophy, political science and economics) into critical constructive conversation with Practical Theology, specifically homiletics and liturgy.

Keywords: liturgy; homiletics; de-colonial; public theology; divine.

\section{The divine service}

The divine service is traditionally understood as a dialogue between God and humanity in the medium of human communication and presentation. ${ }^{1}$ In other words, the divine service uses the art of communicating through language, which includes words, music, signs, bodies and rituals to communicate, and thereby present something of the divine or the religious, even if it is primarily the community's faith in a divine that is presented via the community's self-communication. In other words, what is communicated is presented or comes to present. The communication is not primarily about the transfer of information but a creative poetic act of making present, that which was not present before the communicative presentation. This formulation by Schleiermacher makes it clear what a divine service is not. It is not a classroom or lecture hall where information or knowledge is transferred from an expert (preacher or the Divine Texts) to the listeners who are seen as empty vessels to be filled with divine knowledge as in Freire's (2000:12) criticism of the dominant banking model of pedagogy. Nor is the divine service a mass therapy session, where egos are comforted and rebuilt to survive in the urban jungle. The divine service is not a motivational talk or a talk show. That said, one cannot exclude that learning can happen or that one is comforted or inspired, but that cannot be its purpose. The purpose of the divine service, in this tradition of communicative presentation, is to present something through communication. To present something new, a new subject (reborn subject), a new view of the world (kingdom of God here and now), a new life, resurrection life. This is Badiou's argument with regard to theatre (see Badiou 2013), that the live performance on opening night is the emergence of something new through the performance. For Badiou, 'theatre functions as a kind of laboratory for the experimental production and investigation of new subjectivities, new ideas, and new temporalities' (Badiou 2013:xxiv emphasis added). According to him, theatrical performance is 'not intended to produce knowledge (or for that matter catharsis) but aims primarily at truth $^{2 \prime}$ (Badiou 2013:xxiv). The crucial question that immediately comes to mind is, what exactly is presented, and likewise, what is communicated in this performance, if, in a divine service, one attempts to present or represent, that is communicate, the divine or the religious? For Meyer-Blanck (2011:27), in his interpretation of Schleiermacher, it is not so much the religious or the divine, but faith that is presented. ${ }^{3}$

1.'Gottesdienst als Dialog mit Gott im Medium menschlicher Mitteilung und Darstellung' (The divine service as a dialog with God in the medium of human communication and presentation) Meyer-Blanck (2011:25)

2.For Badiou, 'truths' are not especially certain types of 'knowledge', statements that correspond to something in the external world or are coherent within a given system of statements, but the emergence of something new in a world or discourse through subtraction or decompletion, and the procedures for evaluation and expansion developed around the void suddenly laid bare (Badiou 2013:xxv).

3.Im Gottesdienst tritt der Glaube der Menschen nach außen, er wird zum Zeichen. Die Gemeinschaft stellt etwas dar und sie stellt sich selbst dar. Die Gemeinschaft existiert nur insofern, als sie sich selbst darstellt. Die Gemeinschaft ist überhaupt nur zusammen mit ihrer gemeinsamen Darstellung zu fassen (Meyer-Blanck 2011:27). 
It is more specifically, for him, the faith of the community that is presented, and by this presentation of their communal faith, the faith community is presented - it comes into presence. In other words, through communicative presentation of the faith community's faith, the faith community comes into presence and is thus presented. Later, the article will return to the idea of faith being presented through this act of communication or rather through this communal act of communication, and will specifically focus on Latour's idea of a faith world being presented. Latour's faith world is not the world hereafter, which is believed to be a world far removed or exotic in the sense of being the world after death or heaven somewhere remote to which the only access is to die as a believer. Nor is it the ancient world of the text, and neither is it a world any different from the everyday world one lives in, as it is the very world in which one is a Dasein, but it is transfigured ${ }^{4}$ through faith. One is reborn. For Latour, this transfiguration means that a new relationship to the world - oneself in the world as well as others in the world is created. This is a relationship of radical nearness (in the spatial sense) and of presence in a temporal sense of fulfilment of time, but not time understood as being from the distant past or expected future, but time fulfilled in the present. ${ }^{5}$ In this sense, the communication is, indeed, a communicative presentation, where those who are saved and consequently have become neighbours (near) to each other (see Latour 2013:135), as they have become brothers and sisters, can therefore be presented as being close (present) and no longer distant. This world of neighbours, presented through a communication of faith, can be interpreted as a political act, in Rancièrès (2019:43-44) sense. It is a political act as a world is presented (created) where all the neighbours (all that is present) are presented democratically as they are equal - brothers and sisters. Latour argues that religion - and I add specifically Christian religion, as he speaks nearly exclusively about Christianity in his book - is not about what is far, distant, exotic, other-worldly or transcendental and eternal or in a faraway heaven somewhere but is about that which is close and present, and transforms the near and present into a neighbour. It speaks the close and present into presence, and in that sense, it is a communicative presenting. Latour (2013) argues that belief, in contrast to faith, is about these far away things and that therefore expertise, that is, religious or mystical knowledge (expertise), is necessary to gain access to these faraway places and things. In other words, experts (theologians or priests, or those initiated, or the wise) are necessary to read the ancient or distant texts, understand them, interpret them, and then communicate that which is distant and far to those at hand, but only after expertly interpreting that which is at hand (the near and present). The 'experts' can also be found in the pew, or expert voices from the street, or expert voices of the indigenous people, and as soon as there are experts necessary who help one to cross a distance, one is colonising the liturgical space. To traverse these two impossible distances is, indeed, a tormented

4.The lovers know very well that the talk that saves them from moving apart does not come from afar, but lives amongst them. It lifts their existence without actually changing it; it does not add one bit of information, no knowledge, not a single fact to their little world, yet it has already transfigured that world, from within (Latour 2013:138).

5.So, there exists a form of original utterance that speaks of the present, of definitive presence, of completion, of the fulfilment of time, and which, because it speaks of it in the pront, must al, of the brought for backsiding of the instant toward the past; a form of speech whose sole character is to consitu of the in the to constitute those it is addressed to as being close and saved, a kind of vehicle that differs absolutely from those we've evolved elsewhere to accede to the distant in order to control information about the world (Latour 2013:118). journey. Gräb (2013) tried to seek the near and present in his understanding of religious speech and in his understanding of religion (religion as that which tries to make sense and create meaning from the contingent events in daily life, that is, which is difficult or even impossible to explain - those experiences in life that fall outside the normal day to day experiences), and more specifically his interpretation of lived religion. Religion is about trying to find (often in distant places) information, reasons, meaning to be able to interpret that which is beyond normal everyday understanding and comprehension. Religion for Gräb is then that which helps interpret and explain the contingent and the inexplicable of everyday fate and in that sense expert knowledge is required as the day-to-day knowledge is not sufficient. It is a double movement, firstly, to recognise the lived religious moments (the searching for meaning and sense for the extraordinary of everyday life), and secondly, to interpret the biblical texts as expressions of this sense-making and meaningmaking of the extraordinary in ordinary life.

\section{Gräb: Homiletics as religious speech}

Gräb (2013) argued that a sermon becomes religious speech when it is about the existential concretisation of the Christian faith, as it (Christian theology) offers the language with which to interpret the lived religious experiences of contingency, or of luck and need, as well as experiences of the elemental desires and hopes of a people (Gräb 2013:33). Religion for Gräb ${ }^{6}$ is that which tries to give meaning and sense to that which cannot be explained in 'normal' everyday mundane language, that is, experiences of contingency of life, moments of great luck (fortune) or moments of great need (misfortune), as well as the human desire and, more specifically, the absolute need for meaning and hope. In Lacanian (Lacan 2013:65) terms, religion addresses the gap in the symbolic and imaginary to provide meaning and sense of the real. This, for Lacan, is the task of religion and it is for this reason that Lacan believes that religion will eventually triumph over psychoanalysis - as the desire to explain and give meaning to the inexplicable is too strong, and likewise impossible to live without. One would not have a home (house of being) in which to be if it was not for master signifiers, the names of the Father (God or Logos) who create this house of being: who create the ontology. Humanity driven by this desire to find and give meaning to the inexplicable will again and again, in an eternal return, ${ }^{7}$ turn to religion or science to communicate explanations of that which challenges the mundane, the cracks, holes and lacuna in the mundane stories of everyday life. In Latour's understanding, the moment one speaks of belief one is once again dealing with a beyond that is imaginatively and symbolically created, the beyond normal comprehension, in other words something far or distant, at least in terms of comprehension. Thus, religion in this context of belief refers to something that needs some kind of knowledge, and therefore, an expert who has the ability (who is supposed to know) to overcome the distance, which is either historical distance or mystical distance or epistemological distance, but could also be an eschatological distance of a dreamt future. For Latour, religion in the context of faith is something different, and

6.Sie muss den biblischen Text so interpretieren, dass diese Interpretation auf die religiösen Sinnbedürfnisse der Menschen zu reagieren vermag (Gräb 2013:36-37).

7.As Deleuze argues that the eternal return is the truth of faith (Deleuze 1994:95). 
although religion is shrouded in all these difficulties, there remains a way of speaking religiously, which is not necessarily Gräb's Christian meaning and sense donation that is projected onto lived religious needs and desires. For Latour it is about what speaking does rather than what it communicates - it brings closeness and a fulfilment of time. In a sense, it is the flesh of words $^{8}$ (Rancière 2004a:3). It makes present in both senses of this word - present as in spatial nearness as well as present in the sense of present tense and the fulfilment of time. In that sense, speaking is a political act in Rancière's (2019:43-44) interpretation - as a new world, a new community is spoken into presence. Latour uses the example of two lovers who declare love to one another. In this declaration, they do not seek meanings and interpretations of love, but they speak it to each other, and in that speech their love for one another is rekindled'; it is made present: both spatial nearness and present tense. He uses this example to try and express something of the kind of speaking that does not fall victim to the empire of understanding, namely, communication whose sole purpose is the communication of information (Latour 2013:54). In that sense, one might alter Schleiermacher's formulation into speaking presentation rather than communicative presentation, but only if communication is primarily and always understood as the communication of information. What are the conditions necessary for such speaking, the kind of speaking that speaks a world into existence? Latour (2013:54-55) listed four felicity conditions ${ }^{10}$ for this language game, for this act of speaking that presents through speaking both the present and the near rather than the distant and the far. It is no longer the desire to reach some transcendental reality with a mimetic understanding of language, but it is the creation of reality, the flesh of words (Rancière 2004a), the materialism of language, or rather the materialism of the signifier.

Latour's final condition, 'a unity, an identity, a union or a people (in the lovers' case, a micro-people) finds itself reformed' (Latour 2013:55 emphasis added).

This last condition via a detour repeats Schleiermacher's formulation, as interpreted by Meyer-Blanck, that the congregation (people of faith) are presented in this language act and formed into a community by being presented through their communication. This article has referred to it as a language act because it is more than speech, as, in the case of a congregation,

$8 . F o r$ it is not by describing that words acquire their power: it is by naming, by calling by commanding, by intriguing, by seducing that they slice into the naturalness of existences, set humans on their path, separate them and unite them into communities (Rancière 2004a:3).

9.'What lovers call their love, that love capable of lasting and growing deeper, always materialises for them in the fragility of a risky speech act that forces them to keep on raising the stakes. Depending on how they speak to one another, they either find themselves as distant as strangers or closer than they've ever been' (Latour 2013:51).

10.First condition, whatever is communicated must be communicated in the language of the person to whom it is addressed, without adding the superfluous difficulty of translation. Second condition, 'these formal speeches must be directed to the present situation, to us, here and now, without diverting our attention, without rehashing old grievances, without claiming to settle scores over some old debt. It's the present that's at issue, not the past' (Latour 2013:55). Third condition, 'these injunctions must at no time try to seek a compromise with sentences full of information that might lead, through the intermediary of a chain of references, to access to the distant ..... no rough and ready compromise between words of conversion and words of information, between creating closeness and seeking the distant' (Latour 2013.55). Fourth condition 'the words that give life must have an distant (Latour 2013.55). Fourth condition, 'the words that give life must have an effect, otherwise we say them falsely. This effect can only be the recapturing, at that precise moment, of that lost love, the fragile and temporary redressing which nonetheless in that moment seems to be definitive and salutary - of time. Whereas time was falling heavily from the past and crushing the present (the dead had the living in its grip), now it's lighter, springing up the future (the living has the dead in its grip)' (Latour 2013:55) it includes rituals, music, signs, symbols, and bodies together with the body's ability to smell, taste and touch.

The temptation of this language act, or the danger that lurks in this language act, is that it is transformed into a religious act in Lacan's interpretation of religion, or it transforms into the language of belief, in Latour's sense, and therefore, Latour developed a set of infelicity conditions. ${ }^{11}$

Language: the divine of speech or the sacrament of speaking - the Flesh of the Word or the Body (of believers) of the Word.

Religious speaking (for Latour), divine speech, mitteilende Darstellung (communicative presentation), keeping Latour's warning in mind concerning communication and therefore the reference to speaking presentation, is a speech act, a language act, a linguistic performance, that presents by making present what was far and distant in the here and now. Which is in essence what language does: it makes present. It is what the pharmakon does, it is a gift, a present, as it makes present that which is, and whatever is, is only in the language world: it (whatever it is) is present through language - communicative presentation. Language calls the beings into the Lichtung. This making or creating (poiesis) is exactly what the poem does:

$[T]$ he naming calls. Calling brings closer what it calls. However, this bringing closer does not fetch what is called only in order to set it down in closest proximity to what is present, to find a place for it here. The call does indeed call. Thus, it brings the presence of what was previously uncalled into a nearness. But the call, in calling it here, has already called out to what it calls. Where to? Into the distance in which what is called remains, still absent. (Heidegger 1971:198, see also Meylahn 2013:68ff)

One can maybe refer to this as the sacramental aspect of speech, in the sense that words do what they say. '..., so that they once more become sacramental, that is, they quite simply start saying again what they do?' (Latour 2013:170).

The faith that Latour speaks about, and the faithfulness of words, the faithfulness of speaking, is not about adequatio, as it is not about the perfect copy of reality in words, but it is the power of words to present: to make present. The sermon or the liturgy of a divine service cannot be about adequatio, namely a correct or truthful recollection, copy of an ancient

11. Firstly the words that are supposed to give life are 'said in a foreign language addressed to people remote from us in history, space and culture - so much so
that an infinite period of time would be needed to translate them into the that an infinite period of time would be needed to translate them into the
present tense, well before we even begin to grasp the injunction they once bore' (Latour 2013:56). Secondly, 'even if we could translate them, we wouldn't understand them, for they are no longer addressed to us, here and now, but to those, down there, in very ancient times. For those perfect strangers, they must have had a miraculous power but for us, who are no longer in their sandals, they feel like so much ranting, ridiculous pomposity, crazy makebelieve' (Latour 2013:56). Thirdly, 'to rate them even a tiny bit seriously, we could grope our way along the meandering paths of the sciences, establish bridges and proofs, line up instruments and documents that would allow us to reconnect in thought with those distant times, those stranger peoples, those reconnect in thought with those distant times, those stranger peoples, those bizarre expressions. But then we'd have to pay the high price of exegesis, of archaeology and history. In short, we'd have to accept the constraints of erudition, at the same time as those certainties" (Latour 2013:56-57). Fourthly, the words do not have the slightest effect on (he listeners, besides mayb being of historical (traditional) or aesthetic or even sentimental value. Fifthly, the listeners of these words remain strangers, even enemies that nothing can bring together (Latour 2013:57) 
truth, but it is the repetition of a truth event. One could say that there are traces of truth events in the biblical texts, or that biblical texts are haunted by truth events, but it is impossible and therefore a tormented enterprise to believe oneself able to recollect those truths for today. This recollection would be to try and mimic the truth event by seeking to be faithful to the trace of the truth event in the text. The idea is then to repeat the truth event in the communicative presentation.

[T] he problem is not that the resemblance is unfaithful, but that it is too faithful, still attached to what has been said when already it should be elsewhere, near where the meaning of what has been said must speak. (Rancière 2004a:3)

This, for Latour, is the task of religious speech, which is similar, but with a difference, to Rancière task of politics. 'An imaginative play, as Rancière (2004b:9) argues, that is both mimeses, but also to create a living beauty, to constitute something' (Meylahn 2021:26). In that sense, it is about mimicking, but in the sense of repeating and not recollecting. 'In a certain sense, one is left with the politics of aesthetics (see Rancière 2009:8-9) and the aesthetic duty to create fictions to come' (Meylahn 2021:56), which, in turn, create worlds: speak into existence what they say and not just try and capture (recollect) a faint shadow or ghost of a past existence or experience. Homiletics and liturgy have always been understood as an attempt to capture something of the spirit of the text and present it to today's audience and thus a question of recollection or repeating. Cilliers (2016) also argued for this creative power of words, with regard to creating (poiesis) spaces. He believes that one can create such spaces by interrupting cyclical mythical time with linear prophetic time (Cilliers 2016:155). This is possible, for Cilliers, as he interprets the biblical God as a God of history, who helps one interpret and discern the current time space (phronesis) by remembering the past (anamnesis), as well as anticipate the future (adventus) (Cilliers 2016:160). Here again, one has the classical far and distant of both remembering the past and anticipating the future.

A second danger is in contrasting mythical cyclical time with prophetic linear time, as this reminds one of the two sign regimes that together create the Abstract Machine (Deleuze \& Guattari 2011:111ff) that stratifies and colonises the earth. Thus, I would rather turn towards poiesis understood as universal production ${ }^{12}$ (Ruda 2011:177) that also comes from a kind of Kairos moment, which is understood as communist action ${ }^{13}$ (Ruda 2011). So, there is, indeed, an element of irruption, but not necessarily the irruption of prophetic time within mythical time, but irruption of an event: truth event.

12. This is why true activity, that is, universal production, is true life, that is, the permanent creation of one's own universality. If true life is constitutively universa active life and if therefore life can be said to be creative life, one can conclude that productive life defines a life which in its activity constantly refers back to itself. Marx's conception of human species-life, the life of generic humanity, can be understood as a conception of life living life.' (Ruda 2011:177).

13.The actual communist action names an event; an evental irruption into the structures of historical societal dynamics which lets the specific 'universality of man (Ruda 2011:175), the matter of the ethical space, following the logic of double latency, appear as something that logically lies 'before' (although it is always only accessible 'after') the structures of the state and of civil society (Ruda 2011:173).
Jacques Rancière, in an interview with Anne Marie Oliver (Rancière 2008:174), argues for a poetics of politics that 'consists in reframing the relation between words and things' (see also Meylahn 2021:388). This reframing is the performance of an event. The reframing between words and things is the communicative presentation. In other words, it is the poetics that is a universal production, the creative life of life.

This poiessis has certain similarities with what Cilliers (2016) advocates:

$[I] \mathrm{t}$ is also an event that penetrates and disperses space and time..., so that the phenomenology of time and space becomes filled up, is 'full-filled', with the teleological dimension of grace, meaning and hope. (p. 7)

Cilliers links this idea with the Greek word, chora (Cilliers 2016:12). Chora as that which both gives and receives space-time and yet is prior to space-time and therefore, in this article, it will be linked rather with the idea of ethical space and universal production, as it (chora) is and remains indeterminate and prior, yet it gives, whilst also being that which receives. Such an understanding of chora would delink it from any teleological (far and distant) dimension, by rather thinking chora in relation to universal production, which could be interpreted as fulfilled eschatology, thereby keeping the relation to both grace and hope, but without the teleological expectation, but in the here and now.

\section{Traditional homiletics}

Traditionally, the crafting of a divine service, and specifically a sermon, has been to traverse two great distances. The first distance is a historical and sociocultural distance, namely, the distance between the world of the text and the world of today's readers of the text, which is firstly, difference between the implied meaning of the text for both the original author and the first implied readers of these ancient texts (Bible/sacred scriptures). Secondly, the great distance is the distance to the implied listeners [readers] seeking to understand and interpret the text within the context of their lived religious needs and hopes (Gräb 2013) today. Once both these distances (differences) have been traversed, then there is the possibility of a fusion of horizons between these two worlds, which can then be communicated. The aim or goal of traditional homiletics is to successfully bridge these two distances, so that in a sense, these two worlds come closer together. For such a traversing of such impossible distances, much skill and expertise are necessary, for example the skill to read the ancient texts in their original language (Hebrew, Greek and Latin), as well as the skill to analyse and interpret the contemporary world.

Homiletics in this tradition is then understood as mediation between these worlds, and then consequently communication of a successful fusion of horizons between these two worlds. In the history of homiletics, there have been numerous developments as to how this fusion of horizons is achieved. At times the ancient world of the text was primary and the 
starting point, at other times the present world of the listeners is emphasised and is believed to be the starting point, and at other times the aesthetic mediation itself was emphasised. In such a traditional understanding of homiletics, one thing that cannot be avoided is the traversing of distances and thus, in Latour's words, it can, indeed, be interpreted as a tormenting process. In other words, homiletics can be summed up as a process of exegesis and interpretation of the Christian tradition with the desire to find appropriate words to address the lived religious needs and desires of the congregation sitting before the preacher. It is thus essentially a process of recollecting the meaning and sense that far and distant people in far and distant worlds discovered with regard to their collective lived religious experiences. Homiletics, which is understood as this traversing of distances and seeking to bridge those unbridgeable differences, which seems to be an impossible task, can, indeed, be understood as tormenting, and yet for many it is also extremely fulfilling, and, indeed, for many an honourable calling.

\section{Homiletics as poiēsis}

Religious speech, as Latour understands it, are words that do what they say, or say what they do, and thus could be compared with Badiou's (2009:4) Truth Event. According to Badiou (2009), the political is one of the truth procedures, which is similar to Latour's understanding of the political. The danger of such a truth event is that it could easily, as Badiou warns, be betrayed as it becomes colonial by determining the new space-time - determining the new world, by organising and eventually policing the ontology (including the citizens) of that new world. The word that creates is then the logos of ontology, namely that which determines and thus colonises this new space-time (world) with its mortals and divinities, heaven and earth. Religious speech in Latour's sense, or politics in Rancière's sense, does not determine space-time and does not carry out a world as Heidegger (1971) argues, but it brings into close proximity in the sense of being present (communicative presentation) and it brings time into the fulfilment of time (Latour 2013:118). For Rancière (2004a) it is this flesh of words that is the politics of writing; for Latour (2013) it is the rejoicing of such presence as the result of speaking (writing) that is the religious (and I would add the Christian) speech, yet different to Gräb's understanding of religious speech. But, maybe it has certain similarities to Schleiermacher's concept of communicative presenting. What is presented in Latour's speech of faith or what is presented through speaking (communication) in Rancière's politics? It is all that is, namely all that is made present by the words spoken. Poiesis is the speaking (communication) of the new into presence; it is the speaking of the impossible into possibility. In other words, it is the speaking of the resurrection into presence through the cross. This speaking into presence and into fulfilment of time cannot be an ordering or stratification of the world according to either state-forming or state-maintaining violence (or power), but it is a divine violence that brings the impossible into possibility beyond the laws of the possible. This speaking into presence of the impossible (resurrection) has certain similarities with Rancière's political speaking. For Rancière it is the speaking of the voiceless, the count of the uncounted, the speaking of the demos of democracy (i.e. the impossible) - where all voices are equal, where all count without reason or privilege to be counted (either the traditional police count or the social justice ethical count of the previously uncounted). In the communicative presentation of the Christ-Event (Christ poiessis), there is neither Greek nor Jew, man or woman, free or slave (Gl 3:28). All these voices, communicating a world into presence, are equal. This radical equality could be celebrated, but such a celebration runs the temptation of becoming a new metanarrative that would once again police these different voices under a single logos, as the logic of a celebration of diversity or the joy of multi-culturalism and multi-racialism together with the multi-religious. Such a new metanarrative would police these different voices and order them into various cultural, racial, sexual, religious groups these different groups might even be equally respected groups, but still ordered and policed into their proper equally respected place of tolerance. The other possibility is an antagonism of various populist groups on the traditional left vs. those on the traditional right and the new-liberal middle that will always seek to police these two extreme voices. Police them into appropriate silence or into appropriate (politically correct) language with various experts explaining the rise and the fall of such movements, in an attempt to contain the violence of antagonism.

\section{Homiletics: From the Cross of Christ}

What is proposed in this article is not multicultural celebration nor antagonism of the various populist movements on the left and the right with the dominant neo-liberal middle that presents itself as fact, but the agony of all these voices being equal. This does not translate into all speaking beings speaking a truth or even the truth, it is not about being equally true as in the idea that one can learn something from all, but they are all equally fantasies, all equally symptoms, all equally fictions (Meylahn 2018) as they are all equally pharmaka, without access to some or other transcendental that gives truth to such a statement of radical equality, but it is a structural truth. This is an unbearable agony - the agony of the cross, where Jesus says: 'Forgive them for they do not know what they are doing', and likewise the agony of Christ's cry of the cross: 'Father why hast thou forsaken me!'. Thus, the agony of all the fictions competing with each other in the convinced belief that each believes their fiction to be true. And the agony of these fictions together with the agony of there being no transcendental beyond these fictions, but that this agony arises from a structural 'truth': the crucifixion. It is from this agony that something new becomes possible - that is undefined, unsignified, but possible as the previously impossible. This agony does not only remind one of the agonism of Mouffe (2013:7 see also Meylahn 2018:122), but more specifically the agony as described by Cioran. ${ }^{14}$ This is 
the agony of the crucifixion of all these fictions, but not a crucifixion in the name of, but a crucifixion of complete forsakenness. Yet, this very crucifixion is also the life of the worlds crafted into presence and fulness of time by the spoken words of faith: the proclamation in word and ritual of the Christ-Event. The crucifixion is the resurrection of these worlds, not in the sense of a dialectical sublimation of the cross in the resurrection, but the crucifixion is the resurrection of worlds called into nearness, called into the fullness of time; just as the pharmakon (the word) is both death and life. It is from this agony that something new becomes possible: a newness that is not defined by a logos, or a new truth. It is not a truth that emerges as in Badiou (2009:4), which can call a new subject into being. However, it is the newness of nothing; the newness and the possibilities of the impossible; the crafting of something new without the belief in a truth, besides the faith in the flesh of words, faith in language that calls into presence and into the fullness of time.

It is for this reason that what is needed is a liturgical space - a space that does not celebrate diversity and thereby imposes a multi-culturalism. It is not a moral space that believes itself to give voice to previously voiceless, or a police space that seeks to allocate spaces to each voice or offer expert interpretations of the different voices, but rather an ethical space (see Ruda 2011:95-96) prior to determination of the voices that calls into responsibility (see Meylahn 2021). It is a repentant space of moving through and experiencing the crucifixion of one's own fiction without access to a higher fiction that sublimates or redeems or saves the broken fragile fictions. The faith that this crucifixion is the resurrection. One could link this crucifixion, even the crucifixion of death in the resurrection, with what Tari (2021a) argues, in conversation with Deleuze and Guattari, namely, 'This mobile and precise point that even destitutes death is what I call the event of communism' (see Tari 2021a). But this faith in the crucifixion, this communication of the crucifixion, should never end in a dark mass, where death and destruction are celebrated, or where deconstruction is prised as the only way. It is not a mass in honour of Thanatos, but the acknowledgement that Thanatos and Eros are one - not one in a yin-yang sense, but One. It is the faith in the crucified word (without belief) that calls into presence and into the fullness of time. Or, as Agamben argues: 'Revolutionary violence alone may cross this threshold. It occurs in the stunning realization of the indissoluble unity of life and death, creation and negation' (Agamben 2009:109).

\section{Towards a non-colonial liturgy}

The book of Job gives a possible guideline towards understanding the possibility of a non-colonial liturgy, as it is not a celebration of deconstruction and gleeful witnessing of how all is destroyed, yet it does place one in that space between

\section{(footnote 14 continues ...)} agony. ... I call agonic only those dramatic moments in the battle between life and
death when the presence of death is experienced consciously and painfully. True agony occurs when you pass into nothingness through death, when a feeling of weariness consumes you irrevocably and death wins. In every true agony there is a weariness consumes you irrevocably and death wins. In every true agony there is a
triumph of death, even though you may continue to live after those moments of weariness (Cioran 1992:14-17). good and evil, between God and Satan - that place between and yet beyond - where none of the three friends' theology or theodicy (the traversing of great distance) or even ethics could truly give answer to Job's plight and Job's refusal to accept any master narrative. Job refuses to accept or to become or to be the scapegoat necessary to re-establish a religious or ideological system (see Girard 1987) of the three 'friends'. His refusal to be a possibility in the various theological or ethical systems places him on the side of the impossible, and therefore, the drive of the 'friends' to make him the scapegoat in an attempt to keep their theology safe. Yet, Job exposes and refuses to be their scapegoat, and thereby places himself in the impossible beyond the law, as a white-hot fire of divine violence that destroys their systems. To move beyond such systems, not towards a new system or utopia, but beyond in the sense of the loss (negation) of everything, loss of destitution of such theological systems and even the loss of the justification of the loss of everything, and then there is the regaining of everything in fourfold and multiple manner.

$[R]$ evolutionary violence is not a violence of means, aimed at the just end of negating the existing system. Rather, it is a violence that negates the self as it negates the other; it awakens a consciousness of the death of the self, even as it visits death on the other. (Agamben 2009:108)

Such revolutionary negation (violence) has the potential to create the impossible possible, namely, resurrection.

This communicative presenting might learn something from the various occupy movements in the last few years. Not in the sense of Butler's (2015) Notes Toward a Performative Theory of Assembly, which is certainly a bodily communication of presence, but still under the master signifier of a particular capitalist understanding of democracy (see Rasmussen 2021), but rather to reflect with Tari (2021b; Rasmussen 2021) on his idea of destitution - in other words a communicative presenting of destitution (communicative presentation of the Cross) as a resurrection act or revolutionary act without any specific goal or interpretation of the common good, but new life beyond good and evil. Badiou interprets theatre as a 'particularly active form of thought, an action of thought'. This is what liturgy is as well: an action of thought or an action of faith. According to Badiou, the activity of theatrical thinking takes place primarily in the movement from the textual reference to theatrical performance and in relationships amongst its performative elements - actors, staging, audience and so on (Badiou 2013:xxiii). Theatre, ${ }^{15}$ like liturgy or homiletics, is a movement from text to performance:

$[U]$ nder the larger mode of thinking that is Art, theater is especially 'active' insofar as each performance is a singular and transient occurrence that opens the possibility of a specific kind of truth. (Badiou 2013:xxiii)

Opening night, in other words in the presence of an audience, the act happens and with the act the possibility of something

15.Theatre is an experimental procedure for the production of an infinite and eternal truth in the present at the cusp of art and politics by finite, transient means (Badiou 2013:xxvii). 
new 'through the collective work of writers, actors, painters, musicians, audience, and so on' (Badiou 2013:xxiv). The truth that is theatrically performed in a divine service is the truth of the Christ-Event - the void of being God forsaken in the death of God.

Theatre for Badiou, and liturgy of a divine service for this article, is the one artform that stands next to (or supposes) politics $^{16}$ (Badiou 2013:xxv); politics, as understood by Rancière as the creation, speaking into being, of something new. 'Theater's truth procedures are always addressed to the present, to "our situation in history," and as such they produce a new type of temporality' (Badiou 2013:xxvi).

Coming back to Agamben and the question of what kind of thought act or faith act (performance or communicative presentation) would a liturgy be? Revolutionary violence, Agamben (2009:108) argues, can be described as a passion, the passion of self-negation and self-sacrifice, which links it immediately with the cross and Christ's call to his followers: to pick up their Cross and follow him (Matt 16:24).

It is from this nudity (see Agamben 2011:55-91), this destituent power, that the speaking of words of nearness and presence as the fulfilment of time become possible. This brings one back to the Eastern theological tradition and John of Damascus and Basil the Great who interpreted nudity of the garden of Eden very differently to St. Augustine (see Agamben 2011:81). The state of humanity before sin is the full contemplation of God, and therefore, a fulfilment of time and space. This contemplation and fulfilment of time and nearness of space are destroyed by $\sin$. Sin, in this Eastern theological tradition, is understood as identifying in this fullness a lack. Once this fulness and fulfilment are interpreted as lack, this lack needs to be 'fixed', and it can only be overcome with knowledge, things and techniques. This is exactly what the serpent meant when it tempted Adam and Eve with the fruit of the tree of knowledge. It refers to knowledge, which is the ability to colonise oneself and the other and that which creates distance between oneself and the other as well as Big Other.

He continues and argues, '[o]nly those who consciously confront their own negation through violence may shake off "all the muck of ages" and begin the world anew' (Agamben 2009:108-109).

It is the destituent ${ }^{17}$ power of the crucifixion or the destituent power of Job that has the ability, like divine violence, to create (make present) something absolutely new, beyond state maintaining or state creating violence, or beyond good and evil and beyond just and injustice. It is the destituent power of the cross that has the negating power to move beyond the classifications and identifications of the oppressor and the oppressed, master and slave, Jew or Greek, man or woman.

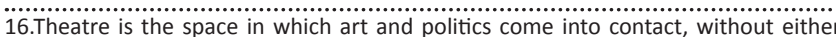
politicising art or aestheticising politics (Badiou 2013:xxv).... : the three conditions the three factors whose knot is the political (masses, multiple subject-effects or the three factors whose knot is the political (masses, multiple
positions, a thought or conceptual referent) (Badiou 2013:xxv).

17.This is Wakefield's translation of Agamben's Potenza destituente; she chose this translation as it brings out the middle voice, as it is a destitute power rather than the action of a specific subject on an object (Agamben 2014:65).
The destituent power of crucifixion has the ability to create something absolutely new, namely resurrection life - because it is not an active power in the name of some arche or telos. As long as violence or power is all about negating the other or Other, it is repressive violence (which enforces law) or delinquent violence (which defies law), and these two are no different from the violence that aims at establishing new laws and new power (see Agamben 2009:108). Only destituent power which negates itself and thereby negates the other, as in a general strike, is the power from which something new can emerge. Agamben (2014:69-70) refers to feasts, dance, poetry and acting to describe something of this destituent power as an inoperative operation, as these activities negate the normal purposeful tasks and activities, thereby disrupting these normal and normative activities. The reason for the necessity of such a destituent power or inoperative operation is to escape from the cycle of violence that only repeats what is already present. ${ }^{18}$ Reflecting on Walter Benjamin's (1977) Zur Kritik der Gewalt (Critique of violence), Agamben differentiates between constituent power and destituent power; he does this in the context of the difference Benjamin creates between the general strike and the political strike. ${ }^{19}$

To explain what he means, Agamben turns to Saint Paul, specifically in his letters to the Corinthians (1 Cor 15:24) and Romans (Rm 10:4), focusing on the relationship between the Christ (Messiah) and the law. Christ, the Messiah, will render inoperative all rule, all authority and all power (1 Cor 15:24) and at the same time, fulfill the law (Rm 10:4). Likewise, the believers, the followers of Christ, have been rendered inoperative with respect to the law ( $\operatorname{Rm} 7: 5-6)$. Luther, according to Agamben, translates Katargein with aufheben, which has both these meanings: to destroy and to conserve (Agamben 2014:71), and probably had an influence on Hegel's interpretation of dialectical Aufhebung.

It is on the basis of the destituent power of faith that Paul can urge the believers to live as not (1 Cor 7). This as not is a form of life ${ }^{20}-$ a passive active form of life that is a gift of grace and faith, and in this passive-active sense it can be understood as being in the middle voice between or beyond active and passive (see Agamben 2014:68). This power in the middle voice cannot be interpreted as a task to be fulfilled, but it is a form of life, namely a form of life that is given in and through the destituent power of the cross. ${ }^{21}$ It is a form of life that is communicated into presence through the Christ-Event as a performance of Christ-poiēsis.

18. A power that was only just overthrown by violence will rise again in another form, in the incessant, inevitable dialectic between constituent power and constituted power, the incessant, inevitable dialectic between constituent power and constituted power,
violence which makes the law and violence that preserves it (Agamben 2014:70).

19.The difference between veranlassen, 'to induce, to provoke', and vollziehn, 'to accomplish, to realize', expresses the opposition between constituent power which destroys and always recreates new forms of law, without ever completely destituting it, and destituent power, which, in deposing law once and for all, immediately inaugurates a new reality. 'It follows that the first of these operations is lawmaking but the second anarchic' (page 197) (Agamben 2014:71).

20.'A form-of-life is, in this sense, that which unrelentingly deposes the social condition in which it finds itself living, without negating them but simply using them' (Agamben 2014:71-72). He continues and says, "[u]se" names here the deposing potentiality in the Christ form of life, which destitutes "the figures of this world (to schema tou kosmou toutou)"' (Agamben 2014:72).

21.The destitution of power and its works is an arduous task, because it is first of al and only in a form-of-life that it can be carried out. Only a form-of-life is constitutively destituent (Agamben 2014:72) 
The Latin grammarians had a specific understanding of deponents, which are similar to middle voice verbs. In other words, they cannot be properly called active or passive. It is with the help of an interpretation of middle voice verbs or dependents that one can understand something of the form of life of a Christian ${ }^{22}$ - the form of the Christian life that is spoken and enacted into presence (nearness) and in the fulfilment of time through the liturgy and sermon. Maybe in the film 'Jesus of Montreal' by Arcand (1989), something of a non-colonial liturgy and homiletics is portrayed. It is not the historical Jesus, the distant and far Jesus that is sought to be understood and then translated into today's language, which would be tormented speech in Latour's thinking.

The lead actor does, indeed, perform research on the historical Jesus, and he discovers the torment the church has gone through to construct, protect and develop a closed system of knowledge: Dogma.

The whole movie is about the nearness and the fullness of time - as the Story of Jesus is not recollected from the distant past, but the Christ Event (incarnation - Crucifixion Resurrection) is repeated in the here and now - and thus, Christ is proclaimed near and in the fulfilment of time. The Christ event itself is repeated in the film. This can also be seen in other films, like As it is in heaven (Pollak 2007) as well as Adam's Apples (Jensen 2005), to name but two films. These films do not seek to cross the distance to the religious feelings or experiences of the viewers but just proclaim the nearness and the fulfillment of the Christ Event and thus speak of a non-colonial world into being.

\section{Acknowledgements Competing interests}

The author declares that they have no financial or personal relationships that may have inappropriately influenced them in writing this article.

\section{Author's contributions}

J.A-M. is the sole author of this article.

\section{Ethical considerations}

This study followed all ethical standards for research without any direct contact with human or animal subjects.

\section{Funding information}

This research work received no specific grant from any funding agency in the public, commercial or not-for-profit sectors.

\footnotetext{
22. What do the middle or deponent verbs 'depose'? They do not express an operation, rather they depose it, neutralise and render it inoperative, and, in this way, expose it. The subject is not merely, in the words of Benveniste, internal to the process, but, having deposed its action, it is exposed and put in question together with it. In this sense, these verbs can offer the paradigm to think in a new way not only action
} and praxis but also the theory of the subject (Agamben 2014:72).

\section{Data availability}

Data sharing is not applicable to this article as no new data were created or analysed in this study.

\section{Disclaimer}

The views and opinions expressed in this article are those of the author and do not necessarily reflect the official policy or position of any affiliated agency of the author.

\section{References}

Agamben, G., 2009, 'On the limits of violence, translated Elisabeth Fay', Diacritics 39(4), 103-111. https://doi.org/10.1353/dia.2009.0034

Agamben, G., 2011, Nudities, transl. D. Kishik \& S. Pedtella, Stanford University Press, Stanford, CA.

Agamben, G., 2014, 'What is a destituent power', transl. S. Wakefield, in Environment and Planning D: Society and Space 32(1), 65-74. https://doi.org/10.1068/ d3201tra

Badiou, A., 2009, Logics of worlds: Being and event, 2, transl. A. Toscano, Continuum, London.

Badiou, A., 2013, The incident at Antioch, a tragedy in three acts, transl. S. Spitzer, Columbia University Press, New York, NY.

Benjamin, W., 1977, 'Zur Kritik der Gewalt', in R. Tiedemann (ed.), Gesammelte Schriften II, p. 1, Frankfurt am Main, Suhrkamp.

Butler, J., 2015, Notes toward a performative theory of assembly, Harvard University Press, London.

Cilliers, J., 2016, A space for grace: Towards an aesthetics of preaching, Sun Media, Stellenbosch.

Cioran, E., 1992, On the heights of despair, transl. I. Zarifopol-Johnston, University of Chicago Press, Chicago, IL.

Deleuze, G., 1994, Difference \& repetition, transl. P. Patton, Columbia University Press, New York, NY.

Deleuze, G. \& Guattari, F., 2011, A thousand plateaus: Capitalism and Schizophrenia transl. B. Massumi, University of Minnesota Press, Minneapolis, MN.

Freire, P., 2000, Pedagogy of the oppressed, 30th anniversary edn., transl. M.B. Ramos, Continuum, New York, NY.

Girard, R., 1987, Job the victim of his people, transl. Y. Freccero, The Athlone Press, London.

Gräb, W., 2013, Predigtlehre, Vandenhoeck \& Ruprecht, Göttingen.

Heidegger, M., 1971, Poetry, language, thought, transl. A. Hofstadter, Harper \& Row, New York, NY.

Lacan, J., 2013, The triumph of religion preceded by the discourse to Catholics, transl. B. Fink, Polity Press, Cambridge.

Latour, B., 2013, Rejoicing: Or the torments of religious speech, transl. J. Rose, Polity Press, Cambridge.

Meyer-Blanck, M., 2011, Gottesdienstlehre, Möhr Siebeck, Tübingen.

Meylahn, J.A., 2018, Trans-fictional praxis a Christ-poiēsis of imagining non-colonial worlds emerging from the shadows of global villages, Studien zu Religion und Kultur, LIT Verlag, Wien.

Meylahn, J.A., 2021, [Call] Responding and the worlds in between: Doing (non)philosophy in a time of democratic materialism, Lit Verlag, Wien.

Mouffe, C., 2013, Agonistics: Thinking the world politically, Verso, London.

Rancière, J., 2004a, The flesh of words: The politics of writing, transl. C. Mandell, Stanford University Press, Stanford

Rancière, J., 2004b, 'Is there a Deleuzian aesthetics?', transl. R. Djordjevic, in Qui Parle 14(2), 1-44, Duke University Press, Durham.

Rancière, J., 2008, 'Aesthetics against Incarnation: An interview by Anne Marie Oliver,' Critical Inquiry 35(1). https://doi.org/10.1086/595633

Rancière, J., 2009, 'The aesthetic dimension: Aesthetics, politics, knowledge', Critical Inquiry 36(1), 1-19. https://doi.org/10.1086/606120

Rancière, J., 2019, Dissensus: On politics and aesthetics, edited and translated by Steven Corcoran, Bloomsbury Academic, London.

Rasmussen, M.B., 2021, 'Violence and other non-political actions in the new cycle of of revolt', Mute, viewed 15 March 2021, from https://www.metamute.org/ community/your-posts/violence-and-other-non-political-actions-new-cyclerevolt.

Tarì, M., 2021a, 'The saved commune', in non.copyriot.com, viewed 13 May 2021 from https://non.copyriot.com/the-saved-commune/.

Tarì, M., 2021b, There is no unhappy revolution: The communism of destitution, transl. R. Braude, Common Notions, Brooklyn, NY. 